\title{
PEMBERIAN BANTUAN HUKUM TERHADAP MASYARAKAT MISKIN (Studi Pada LKBH IAIN Bengkulu)
}

\author{
Imam Mahdi, dkk \\ IAIN Bengkulu \\ imam.mahdi@iainbengkulu.ac.id
}

\begin{abstract}
Law Number: 20 of 2003 concerning the National Education System, states that education is a conscious and planned effort to create an atmosphere of learning and learning process so that students actively develop their potential to have religious spiritual strength, self-control, personality, intelligence, morals noble, as well as the skills needed by himself, society, nation and state. Based on preliminary observational data obtained by the author at Sint Carolus Catholic High School in Bengkulu City, the total number of students is 263 people, with 129 male and 134 female students. Meanwhile the number of students based on their religion is 48 Muslim students, 71 Catholic students, 96 Christian students, 46 Buddhist students, 1 student Confucius, and 1 student belief stream.
\end{abstract}

Keywords: Implementation, Religious, Multicultural.

\begin{abstract}
Abstrak. UU No. 23 Tahun 2004 ini dianggap baik karena sebagai upaya preventif untuk melindungi pihak-pihak yang lemah dalam rumah tangga Dalam penelitian ini, pengolahan data dilakukan secara deskriptif, analisis, dan kritis. Hasilnya, kriteria kekerasan yang disebutkan dalam UU No. 23 tahun 2004 tersebut pada prinsipnya sudah sesuai dengan ajaran Islam. Hanya saja, dalam rinciannya ada yang tidak sesuai seperti tindakan suami yang menggauli istrinya dengan paksaan karena suami sangat membutuhkannya. Padahal, dalam ajaran Islam isteri merupakan haq al-intifa' suami yang bisa dimanfaatkan oleh suami selama isteri tidak ada halangan syar i untuk berhubungan badan. Sehingga jika suami ingin melakukannya dan isteri menolaknya tanpa alasan yang dibenarkan syara', maka isteri di sini telah melakukan nusyuz, dan suami dianggap tidak melakukan kekerasan, tapi meminta haknya. Sedangkan sanksi yang diterapkan pada tindakan kekerasan dalam rumah tangga meliputi penjara atau denda sebagaimana diatur dalam UU No. 23 tahun 2004, pada dasarnya juga seudah sesuai dengan fungsi utama penerapan hukuman dalam Islam yaitu zawajir (efek jera) dan ta'dib (pembelajaran). Hanya saja, dalam penerapannya ada yang bertentangan dengan tujuan hukuman itu sendiri.
\end{abstract}

Kata Kunci: Implementasi, Religius, Multikultural. 


\section{Pendahuluan}

Bantuan hukum seharusnya memperhatikan faktor-faktor yang menyebabkan ketidakadilan bagi masyarakat miskin dan faktor-faktor penghambat ketika masyarakat miskin berusaha mengakses bantuan hukum tersebut. Pengalaman masyarakat miskin ketika mengakses bantuan hukum itulah yang kemudian dituangkan dalam berbagai peraturan perundangundangan mengenai bantuan hukum sehingga bantuan hukum tidak sematamata diartikan sebagai jasa dari pengacara kepada masyarakat miskin melainkan merefleksikan realitas yang dihadapi.

Orang kaya dan mempunyai kekuasaan, dengan mudah mengakses dan mendapatkan "keadilan", melalui tangan-tangan advokat yang disewanya. Tidak demikian halnya kelompok masyarakat miskin, mereka tidak mampunyai kemampuan untuk memahami hukum dan tidak mampu untuk membayar advokat, hal demikian menyebabkan tidak ada perlakuan yang sama dimuka hukum untuk mengakses keadilan. Problem dasar yang muncul adalah tidak adanya perluasaan akses yang sama bagi setiap warganegara untuk mendapatkan perlakuan yang sama dimuka hukum, meskipun doktrinnya keadilan harus dapat diakses oleh semua warga negara tanpa terkecuali (justice for all/accessible to all). ${ }^{1}$

Masyarakat miskin yang menghadapi masalah hukum harus menghadapi kenyataan bahwa kondisi sosial politik mereka telah menjadikan mereka tidak dapat mengakses bantuan hukum yang mereka butuhkan. Kemiskinan yang berakibat terhadap rendahnya taraf pendidikan dan pengetahuan menjadikan masyarakat tidak sadar akan hak-haknya. Namun, walaupun mereka sadar akan hak-hak ini tidak serta merta menjadikan mereka dapat mendapatkan keadilan yang mereka cari. Sistem hukum disediakan negara bagi mereka dianggap mahal, tidak mudah diakses dan jauh dari tempat tinggal mereka. ${ }^{2}$ Ditambah lagi, saat ini hukum dianggap telah dikomersialisasi, sehingga masyarakat miskin tidak akan lagi mampu mendapatkan keadilan. ${ }^{3}$ Adanya mafia hukum di hampir setiap level instansi hukum ditambah lagi gambaran mengenai advokat yang dianggap mahal dengan tarif yang tidak akan mampu dibayar oleh masyarakat miskin yang penghasilannya hanya cukup untuk makan sehari-hari.

Masalah hukum bagi masyarakat miskin dan marginal bukan sematamata masalah mereka paham aturan hukum atau tidak, tetapi di Negara-negara yang mana masyarakat menderita kemiskinan secara struktural, masalah hukum

\footnotetext{
${ }^{1}$ Pujiono, Bantuan Hukum dalam Perspektif Tanggungjawab Negara, Makalah disampaikan dalam Kegiatan Seminar "Bantuan Hukum dan Akses terhadap Keadilan Bagi Masyarakat Marginal", Semarang, 09 Pebruari 2010

2 Justice for The Poor - The World Bank, Menciptakan Peluang Keadilan, Jakarta: The World Bank, 2005, hal 85

3 Asfinawati, Prolog: Bantuan Hukum Cuma-Cuma dan Komersialisasi, dalam Lembaga Bantuan Hukum Jakarta, Bantuan Hukum Akses Masyarakat Miskin dan Marjinal terhadap Keadilan, (akarta: LBH Jakarta, 2007, hal vi
} 
menyangkut posisi tawar mereka yang rendah jika dihadapkan dengan negara atau para pemilik modal. ${ }^{4}$

Pada awal tahun 1970-an, Lembaga Bantuan Hukum Indonesia mengusung Bantuan Hukum Struktural (BHS) yang ditujukan selain untuk memberikan pendampingan hukum bagi masyarakat miskin yang berkasus juga meningkatkan posisi tawar mereka melalui penyadaran hak-hak mereka dan mendorong perbaikan hukum untuk mengisi kebutuhan masyarakat yang terus berkembang. $^{5}$

Berkaitan dengan status mereka yang miskin, sistem bantuan hukum yang dibangun oleh negara juga tidak berpihak kepada masyarakat miskin yang harusnya menjadi sasaran bantuan hukum. Negara dinilai pasif dalam hal pemberian bantuan hukum bagi kelompok masyarakat miskin ini. Bantuan hukum dikonstruksikan dalam berbagai perundang-undangan hanya berfungsi jika masyarakat berhadapan dengan hukum di pengadilan, bahkan dalam kasus pidana hanya yang diancam hukuman lima tahun atau lebih yang bisa mendapatkan bantuan hukum yang mereka butuhkan tanpa diminta. ${ }^{6}$ Negara tidak melihat bahwa dari hari ke hari masyarakat miskin menghadapi pelanggaran-pelanggaran hak-hak mereka dan mereka tidak bisa mendapatkan bantuan hukum karena negara tidak memasukkan jenis pelanggaran hak ini sebagai kasus yang bisa mendapatkan bantuan hukum.

Bagi masyarakat miskin hukum itu barang yang mahal dan mereka pun merasa tidak memiliki kebutuhan untuk dijamin hak-hak mereka dijamin oleh hukum. Masyarakat miskin adalah pengecualian dari hukum yang menurut mereka seringkali tidak adil dan menutup kesempatan mereka untuk meningkatkan taraf hidup mereka dan ini terjadi di hampir kebanyakan negara berkembang dan miskin di dunia. Mereka bekerja tidak dalam koridor hukum tetapi di luar hukum itu sendiri: buruh yang bekerja tanpa kontrak, usaha yang tidak terdaftar dan mendiami tanah tanpa dokumen legal. Karena itulah, mereka menjadi pihak yang paling rentan untuk dikategorikan sebagai pelanggar hukum dan sekaligus tidak mendapatkan bantuan apapun dari negara ketika haknya dilanggar.

Masyarakat terutama yang miskin tidak berdaya karena faktor-faktor berikut ini: kurangnya partisipasi dalam pengambilan keputusan, kurangnya akses terhadap informasi dan teknologi, prosedur peradilan dan administrasi negara yang tidak adil, tidak efisien dan kurangnya penghargaan terhadap praktek sosial dan pengetahuan budaya. ${ }^{7}$

Patrick Glenn dalam bukunya Legal Traditions of The World menyatakan ketidakefektifan peradilan formal dalam pendapatnya: "(The State) is corrupt distinct

\footnotetext{
${ }^{4}$ Justice for The Poor, op.cit

5 Adnan Buyung Nasution, Pengantar Bantuan Hukum, dalam Lembaga Bantuan Hukum Jakarta, op.cit

${ }^{6}$ Pasal 55-56 Kitab Undang-Undang Hukum Acara Pidana

${ }^{7}$ Laporan Bank Dunia Tahun 2000/2001 dalam 'Poverty is Because Land' / /www.grida.
} 
and distant from the mass of people, who look, absent a viable alternative, too old ways as a means of sustenance. Yet the old ways are not what they were, debilitated by labor migration, partial industrialization, urbanization and more generally by capitalism" ((Negara) itu korup berbeda dan berjarak dari kebanyakan masyarakatnya, absen dalam memberikan alternatif, cara-caranya terlalu tua untuk bisa mensejahterakan rakyatnya. Namun, cara-cara lama itu tidak bisa lagi menggambarkan mereka saat ini, mereka telah dilemahkan oleh migrasi buruh, industrialisasi yang bersifat parsial, urbainisasi dan lebih umum lagi kapitalisme). ${ }^{8}$

Masyarakat miskin seringkali memilih untuk tidak menggunakan mekanisme peradilan formal karena biaya yang dibutuhkan ketika mengakses pengadilan tersebut. Survei yang dilakukan oleh Mahkamah Agung dan AUSAID terhadap pengguna peradilan agama menemukan bahwa tingginya perempuan kepala keluarga yang mengakses keadilan melalui pengadilan agama. Survei menunjukkan bahwa pengguna pengadilan agama $42 \%$ adalah para perempuan kepala keluarga. Mereka yang pada umumnya menikah tanpa tercatat secara hukum, harus mau tidak mau harus mengakses pengadilan agama untuk meminta itsbat nikah, penetapan perceraian, gugat cerai dan sebagainya. Sebagian dari perempuan ini, tidak mendapat hak-hak mereka setelah bercerai dengan suaminya.'

Dengan tingginya harapan yang digantungkan kepada UU 16 Tahun 2011, apakah kesalahan-kesalahan pengaturan di masa lalu masih terulang lagi. Beberapa jaringan masyarakat sipil (civil society) yang mendorong dan memberi masukan terhadap Rancangan Undang-Undang (RUU) Bantuan Hukum antara lain: Jaringan Koalisi Masyarakat Sipil untuk Bantuan Hukum $(\mathrm{KuBAH})^{10}$, Pos Bantuan Hukum PERADI ${ }^{11}$, Jaringan Paralegal Indonesia (JPI) ${ }^{12}$ dan jaringan LKBH Kampus ${ }^{13}$.

${ }^{8}$ H. Patrick Glenn dalam Justice for The Poor - The World Bank, Forging The Middle Ground-Engaging Non State Justice in Indonesia, Jakarta: The World Bank, 2008, hal 3

9 Cate Sumner, Memberi Keadilan Bagi Para Pencari Keadilan, Sebuah Laporan Tentang Pengadilan Agama Indonesia:Penelitian tabun 2007 tentang Akses dan Kesetaraan Jakarta: Mahkamah Agung dan Ausaid, 2008, hal 13-14

${ }^{10}$ Koalisi Masyarakat Sipil untuk UU Nomor 16 Tahun 2011 (KUBAH) merupakan kumpulan organisasi masyarakat sipil yang mempunyai tujuan untuk mendorong adanya UU Nomor 16 Tahun 2011 di Indonesia. KuBah Bantuan Hukum (KUBAH) (YLBHI, LBH Jakarta, LBH Bandung, LBH Semarang, LBH Yogya, LBH Surabaya, LBH Bali, LBH Makasar, LBH Manado, LBH Papua, LBH Banda Aceh, LBH Medan, LBH Padang, LBH Lampung, LBH Palembang, PBHI, LBH Apik, LBH Pers, LBH Masyarakat, LBH Mawar Saron, Elsam, Kontas, KRHN, Leip, PSHK, MaPPI FHUI, ICW, Walhi, Aman, Sawit Watch). Salah satu hal yang kental diadvokasi oleh jaringan ini adalah mengenai pentingnya bantuan hukum tidak dibawah Kementrian tetapi dibawah suatu Komisi yang independen. Pendapat KuBAH mengenai RUU Bantuan dapat dibaca di www.bantuanhukum.or.id/index.php/id/berita/press-release/494-ruu-bantuan-hukum

${ }^{11}$ Ahmad F. Assegaf dkk, "Pandangan PBH PERADI terbadap RUU Bantuan Hukum Versi Badan Legislasi DPR - RI”, Jakarta: Juli 2010

${ }^{12}$ Jaringan Paralegal Indonesia adalah jaringan lembaga penyedia layanan paralegal yang bertujuan memberdayakan paralegal untuk mendorong adanya pengakuan negara atas peran 
Sejak berdirinya LKBH IAIN Bengkulu Tahun 2013 sampai 2016, kondisi objektif yang dimiliki belum memadai, hal ini disebabkan minimnya dukungan dari Institusi baik mengenai sarana maupun prasarana, bahkan sejak berdirinya LKBH IAIN Bengkulu masih minimnya dukungan bantuan dana.

Dalam pemberian bantuan kepada masyarakat miskin LKBH IAIN Bengkulu sudah memberikan bantuan kepada masyarakat lebih kurang 400 masyarakat baik dari Kota maupun di luar kota Bengkulu, terutama berkaitan dengan penyelesaian Hukum Keluarga yang difokuskan perkaranya di Pengadilan Agama Kelas 1A Bengkulu.

\section{Hasil dan Pembahasan}

A. Pemberian Bantuan Hukum Terhadap Masyarakat Miskin

Dalam Al-Qur'an dan Hadits telah dijelaskan bahwa Allah SW'T memerintahkan untuk saling tolong menolong antara manusia dalam kebaikan dan melarang tolong menolong tersebut dilakukan untuk mengerjakan kemungkaran dan maksiat kepada Allah SWT, hal ini tertuang dalam Al-Qur'an Surat Al-Maidah ayat 2:

Artinya: "dan tolong - menolonglah kamu dalam (mengerjakan) kebajikan dan takwa, dan jangan tolong-menolong dalam berbuat dosa dan pelanggaran. Dan bertakwalah kamu kepada Allah, sesungguhnya Allah amat berat siksa-Nya".

Ismail Ibnu Katsir dalam Mukhtasar Tafsirnya seperti dikutip Abdul Djamal mengatakan bahwa dalam firman Allah ta'ala:

"dan tolong menolonglah dalam kebajikan dan janganlah tolong menolong dalam kejahatan" sesungguhnya Allah ta'ala memerintahkan kepada hambanya yang beriman dengan cara tolong menolong atas perbuatan kebaikan yaitu kebajikan, dan menjauhi segala kerusakan yaitu dengan bertakwa, dan juga Allah melarang kita untuk saling tolong menolong dalam kebathilan, berbuat dosa dan pelanggaran. ${ }^{14}$

paralegal dan penyediaan akses informasi keparalegalan bagi organisasi-organisasi paralegal. Lembaga Penelitian, Pendidikan, dan Penerangan Ekonomi Sosial (LP3ES), RACA Institute, Perhimpunan Bantuan Hukum dan HAM Indonesia (PBHI) Nasional, Lembaga Bantuan Hukum FAS, Federasi LBH , Institute Titian Perdamaian (ITP), Perkumpulan Perempuan Kepala Keluarga (PEKKA). Analisa dan Kritik JPI terhadap RUU Nomor 16 Tahun 2011 dapat dibaca di http://www.paralegalindonesia.org/category/analisis/

${ }_{13}$ Indonesian Legal Resource Center (ILRC) dan Forum Solidaritas LKBH Kampus didukung oleh Open Society Institute menyuusn suatu position paper untuk memberi masukan terhadap RUU Nomor 16 Tahun 2011 dengan judul "Menjamin Hak. Atas Bantuan Hukum Bagi Masyarakat Miskin dan Marginal: Position Paper RUU Nomor 16 Tabun 2011 dan Peran LKBH Kampus' pada Agustus 2010

${ }^{14}$ Abdul djamal, Hukum Islam Berdasarkan Ketentuan Kurikulum Konsorsium Ilmu bukum. Cet 1, (Bandung : Maju Mundur, 2002), h. 98 
Dalam Hadits yang diriwayatkan oleh Abu Hurairah r.a dijelaskan pula Rasulullah SAW bersabda:

'Siapa yang menyelesaikan kesulitan seorang mu'min dari berbagai kesulitan-kesulitan dunia, niscaya Allah akan memudahkan kesulitankesulitannya hari kiamat, dan siapa yang memudahkan orang yang sedang kesulitan niscaya akan Allah mudahkan baginya di dunia dan akhirat dan siapa yang menutupi (aib) seorang muslim Allah akan tutupkan aibnya di dunia dan akhirat. Allah selalu menolong hambanya selama hambanya menolong saudaranya" (H.R. Muslim) ${ }^{15}$.

Ayat dan hadits di atas telah dijelaskan bahwa tolong menolong itu sangat dianjurkan oleh agama baik menolong itu dalam hal-hal yang bersifat keduniaan maupun dalam hal-hal yang bersifat keukhrawian. Salah satu bentuk tolong menolong dalam hal keduniaan adalah memberikan bantuan hukum kepada orang yang membutuhkannnya sesuai dengan apa yang disebutkan dalam ayat Al-Qur'an dan Al-Hadits di atas. Hal inilah yang mempengaruhi pemberian bantuan hukum bagi masyarakat yang tidak mampu secara ekonomis maupun secara keilmuan.

Gugatan ataupun permohonan berperkara di pengadilan bisa diajukan secara lisan ataupun tertulis, tetapi dalam perkembangan hukum dewasa ini, gugatan ataupun permohonan harus diajukan secara tertulis. Masyarakat yang tidak mampu dan awam hukum dalam mengajukan perkaranya ke pengadilan agama sering kali dihadapkan pada aturan dan bahasa hukum yang terkadang kaku dan prosedural. Semuanya harus dilakukan sesuai dengan aturan hukum itu sendiri atau jika tidak permohonan atau gugatan yang diajukan akan ditolak oleh pengadilan padahal bisa jadi hanya karena tidak memenuhi aspek prosedural hukum.

Undang-Undang Dasar 1945 pasal 28 D (1) menyatakan dengan tegas bahwa setiap orang berhak atas pengakuan, jaminan, perlindungan, dan kepastian hukum yang adil serta perlakuan yang sama dihadapan hukum. Jaminan negara ini kemudian dijabarkan dalam berbagai undang-undang dan peraturan yang berkaitan dengan akses masyarakat terhadap hukum dan keadilan.

Pengadilan juga mempunyai asas aktif memberi bantuan asas ini dicantumkan dalam Pasal 58 ayat (2) UU No. 7 Tahun 1989 Jo. Pasal 5 ayat 2 UU no.14 Tahun 1970 yang berbunyi: "Pengadilan membantu para pencari keadilan dan berusaha sekeras-kerasnya mengatasi segala hambatan dan rintangan untuk tercapainya peradilan yang sederhana, cepat, dan biaya

\footnotetext{
${ }^{15}$ Aldin Isri Mustofa, Terjemahan Shabih Muslim Jilid 1, ( Semarang :CV Asy-Syifa, 1998), h. 36
} 
ringan"16. Pasal 56 UU No. 48/2009 Tentang Kekuasaan Kehakiman dan pasal 60 B UU No. 50/2009 Tentang Perubahan Kedua Atas UU No. 7/1989 Tentang Peradilan Agama menyebutkan bahwa "setiap orang yang tersangkut perkara berhak memperoleh bantuan hukum dan negara menanggung biaya perkara bagi pencari keadilan yang tidak mampu"17.

Pasal 57 UU No. 48 Tahun 2009 tentang Kekuasaan Kehakiman dan Pasal 60 (c) UU No. 50 Tahun 2009 tentang Peradilan Agama juga mengatur bahwa "di setiap pengadilan dibentuk Pos Bantuan Hukum untuk pencari keadilan yang tidak mampu dalam memperoleh bantuan hukum" ${ }^{\prime 18}$. Dalam ayat berikutnya disebutkan bahwa bantuan hukum tersebut diberikan secara cumacuma pada semua tingkat peradilan, yaitu pada tingkat pertama, banding, dan kasasi sampai putusan terhadap perkara tersebut telah memperoleh kekuatan hukum tetap.

Hal ini didukung dengan kewajiban dari advokat dalam Undang-undang No.18 Tahun 2003 Tentang Advokat yang telah mengatur secara tegas mengenai kewajiban advokat untuk memberikan bantuan hokum secara cuma-cuma sebagai bagian dari profesi. Dalam hal advokat tidak melakukan perbuatan yang bertentangan dengan kewajiban profesi sehingga dapat diberlakukan sanksi. Untuk mendukung pelaksanaan kewajiban pemberian bantuan hukum secara cuma-cuma oleh advokat maka dibutuhkan peran optimal dari organisasi profesi advokat itu sendiri.

Dalam Surat Edaran Mahkamah Agung (SEMA) Nomor 10 Tahun 2010 diatur tentang pedoman pemberian bantuan hukum, khususnya dalam pembuatan surat gugatan/permohonan dan perkara jinayat, perkara prodeo serta sidang keliling diperlukan sebagai bentuk pelaksanaan amanat undangundang dan rujukan dalam menjamin optimalisasi akses masyarakat miskin dan termarjinalkan terhadap Pengadilan Agama/Mahkamah Syar'iyah. Dalam Surat Edaran MA yang menjelaskan tentang Pos Bantuan Hukum yang tercantum dalam lampiran B (SEMA No.10 Tahun 2010) pada bagian Tiga tentang Pos Bantuan Hukum (Posbakum) yang tercantum dalam pasal $16-23$. Ringkasnya poin-poin penting dalam pelaksanaan serta pembentukan Pos Bantuan Hukum adalah $^{19}$ :

1. Jenis Jasa yang diberikan adalah berupa pemberian informasi, konsultasi, advis, dan pembuatan surat gugatan/permohonan.

2. Pemberian Jasa di Pos Bantuan Hukum adalah: Advokat, Sarjana Hukum, dan Sarjana Syariah.

\footnotetext{
${ }^{16} \mathrm{Jaenal}$ Aripin, Himpunan Undang-Undang Kekuasaan Kehakiman. Cet ke 1, (Jakarta: Kencana Prenada Media grup, 2010), h. 637

${ }^{17}$ Retno Wulan susanto, Iskandar Oeripkartawinata, Hukum Acara Perdata Dalam Teori dan Praktek. Cet ke 6, (Bandung :Penerbit Maju Mundur, 1979), h. 325

${ }^{18}$ M. Yahya Harahap, Kedudukan kewenangan dan acara peradilan agama uu no. 7 tahun 1989. Cet ke 5, ( Jakarta:Sinar Grafika, 2009), h. 90-96

19 Soerjono Soekanto dkk, Bantuan Hukum Suatu Tinjanan Sosial Yuridis, Cet. ke 1, (Jakarta: PT. Ghalia Indonesia, 1983), h. 14
} 
3. Pemberi Jasa yang akan bertugas di Pos Bantuan Hukum ditunjuk oleh Ketua Pengadilan Agama melalui kerjasama kelembagaan.

4. Yang berhak menerima jasa dari Pos Bantuan Hukum adalah orang yang tidak mampu membayar jasa advokat terutama perempuan dan anak-anak serta penyandang disabilitas sesuai peraturan perundang-undangan yang berlaku, baik sebagai penggugat/pemohon maupun tergugat/termohon. Setelah diterbitkannya SEMA No. 10 Tahun 2010 tentang Pedoman Pemberian Bantuan Hukum.

Tujuan adanya bantuan hukum yang diberikan oleh Posbakum, sebagaimana pasal 2 SEMA No.10 Tahun 2010 tentang Pedoman Pemberian Bantuan Hukum di lingkungan peradilan agama adalah :

1. Membantu masyarakat pencari keadilan yang tidak mampu secara ekonomis dalam menjalankan proses hukum di pengadilan;

2. Meningkatkan akses terhadap keadilan;

3. Meningkatkan kesadaran dan pengetahuan masyarakat tentang hukum melalui penghargaan, pemenuhan dan perlindungan hukum terhadap hak dan kewajibannya, dan

4. Memberikan pelayanan prima kepada masyarakat pencari keadilan. Dari tujuan tersebut bisa dilihat bagaimana upaya dari lembaga peradilan untuk memberikan yang terbaik bagi masyarakat pencari keadilan, baik melalui cara beracara secara cuma-cuma (prodeo), pelaksanaan sidang keliling maupun mendapatkan bantuan hukum seperti advis hukum maupun pembuatan gugatan.

Dari uraian diatas sudah tergambar bahwa peran Pos Bantuan Hukum (Posbakum) dan Lembaga Konsultasi Bantuan Hukum (LKBH) dalam pencari keadilan yang berperkara di pengadilan agama sangatlah bermanfaat. Akan tetapi dalam keadaan di lapangan masih banyak masyarakat yang belum begitu memahami dan belum sepenuhnya tahu apa saja sebenarnya peran dan fungsi Posbakum dan LKBH tersebut yang mana salah satu peran dan fungsinya yaitu memberikan bantuan kepada masyarakat yang kurang mampu atau miskin.

1. Pemberian Bantuan Hukum di LKBH IAIN Bengkulu

Pemberian bantuan hukum terhadap masyarakat miskin atau tidak mampu sejak berdirinya Lembaga Konsultasi Bantuan Hukum (LKBH) IAIN Bengkulu dari tahun 2013 sampai dengan sekarang sudah berjalan dan menerima banyak kasus keperdataan yang tangani.

Menurut salah seorang pengurus LKBH IAIN Bengkulu ada beberapa cara pemberian bantuan kepada masyarakat miskin yang dilakukan oleh LKBH IAIN Bengkulu, yaitu:

1) Masyarakat/Klien berkonsultasi kepada LKBH

2) Masyarakat melakukan pendaftaran (mengisi formulir dan biodata yang disediakan oleh $\mathrm{LKBH}$ ) 
3) Mengajukan permohonan secara tertulis

4) Direktur LKBH melakukan penunjukan konsultan

5) Klien berkonsultasi bersama konsultan yang telah ditunjuk yaitu tentang pembuatan legall officer/gelar perkara.

6) Dilanjutkan konsultasi masalah bantuan hukum baik litigasi maupun non litigasi.

7) Penunjukan penangan perkara.

8) Kasus selesai atau perkara selesai

9) Sekretariat mengarrsipkan dan pemberkasan laporan.

a. Prosedur dan Tata Cara Pengajuan Bantuan Hukum

Dalam mengajukan bantuan hukum melalui Lembaga Konsultasi Bantuan Hukum (LKBH) dan Pos Bantuan Hukum (Posbakum) ada beberapa hal yang harus dipenuhi oleh setiap orang yang mengajukannnya. Dan semua persyaratan tersebut harus dipenuhi terlebih dahulu. Adapun mekanisme pemberian layanan sebagaimana terdapat dalam pasal 32 PERMA No. 1 Tahun 2014 sebagai berikut:

1) Masyarakat/klien berkonsultasi kepada LKBH

Masyarakat sebelum mengajukan permohonan dan mengisi formulir pendaftaran kepada LKBH terlebih dahulu melakukan konsultasi/berkonsultasi kepada bagian sekretariat. Hal ini bertujuan agar siapa saja yang mengajukan permohonan kepada pihak Lembaga Konsultasi dan Bantuan Hukum yang ada dapat memberikan data mereka sesuai dengan prosedur yang diinginkan oleh pihak LKBH.

Menurut salah seorang sekretariat LKBH IAIN Bengkulu Etry Mike, MH mengungkapkan bahwa setiap yang ingin mengajukan permohonan bantuan hukum ke pihak LKBH setelah masyarakat/kelien berkonsultasi kepada kami, maka selanjutnya klien mengisi formulir pendaftaran terlebih dahulu, karena ini adalah syarat utama yang harus dipenuhi bagi setiap yang ingin medapatkan bantuan hukum melalui LKBH yang ada secara Cuma-Cuma. Hal ini sesuai dengan Peraturan Mahkamah Agung Tahun 2014, bahwa setiap yang akan menerima bantuan hukum harus sesuai dengan prosedur yang ada ${ }^{20}$. Dari masyarakat yang mengajukan bantuan hukum merasa tidak keberatan dan sangat menerima, dikarenakan dijelaskan secara detail dan kekeluargaan sehingga mudah dipahami dan dimengerti.

Memang ada salah satu penerima bantuan hukum yang sangat perlu sekali dijelaskan, sebab keterbatasan latar pendidikan sehingga harus dengan pelan dan pasti menjelaskan terkait prosedur dan tata cara menerima bantuan hukum.

${ }^{20}$ Etry Mike, MH Petugas/sekretariat di Lembaga Konsultasi dan Bantuan Hukum (LKBH) IAIN Bengkulu, Wawancara. Tanggal 17 Juli 2017 
Dan walapun terbatasnya tempat dan sarana prasarana, namun proses penerima bantuan bagi masyarakat miskin tetap berjalan sesuai dengan aturan yang berlaku ${ }^{21}$.

1) Melakukan pendaftaran

Seusuai dengan ketentuan yang berlaku di LKBH setelah klien berkonsultasi maka sekretariat LKBH IAIN Bengkulu menyarankan kepada klien untuk melakukan pendaftaran dan mengisi formulir/ biodata yang jelas.

Masyarakat/klien yang sudah mengisi formulir dan memenuhi persyaratan sebagaimana yang dimaksud dalam pasal 22 ayat (2) dapat langsung menerima layanan bantuan hukum dari LKBH yang ada dimana mereka mengajukannnya.

Setelah melengkapi dan mengisi formulir data yang telah disediakan, pihak yang akan menerima bantuan hukum menyerahkan berkas tersebut kepada sekeretariat sesuai dengan persyaratan yang ada, dan kemudian pihak LKBH langsung memberikan layanan bantuan hukum yakni dengan cara berdisuksi atau dialog terkait masalah yang dihadapi terkait masalah keluarga, masalah harta benda dan masalah lainnya.

2) Klien melakukan pengajuan permohononan bantuan hukum

Pemberian layanan bantuan hukum yang disediakan oleh LKBH IAIN Bengkulu akan mengkompilasikan berkas perkara penerima layanan Bantuan Hukum yang ada terdiri dari:

a) Formulir permohonan.

Formulir permohonan diisi oleh pihak yang mengajukan, yakni diisi sesuai aturan yang dibuat oleh pihak LKBH yakni disesuai dengan permasalahan yang akan diajukan.

b) Dokumen persyaratan sebagaimana dimaksud dalam pasal 22 ayat (2).

Terkait masalah dokumen persyaratan itu mutlak dan harus disiapkan oleh pihak yang mengajukan/ pemohon bantuan hukum.

c) Pernyataan telah diberlakukannya layanan yang ditandatangani oleh LKBH dan penerima layanan.

Setelah semua berkas dan formulir diisi, pihak yang mengajukan layanan bantuan hukum membuat pernyataan.

d) Penerima layanan Bantuan Hukum yang disediakan oleh pihak LKBH selanjutnya diserahkan ke Posbakum yang ada di Pengadilan Agama.

Menurut salah seorang pengurus LKBH IAIN Bengkulu, setelah menerima berkas, formulir dan surat pernyataan dari pihak pemohon bantuan hukum, LKBH IAIN Bengkulu menyerahkan ke Pos Bantuan Hukum yang ada di Pengadilan Agama ${ }^{22}$.

e) Selanjutnya penerima layanan memerlukan bantuan hukum berupa pendampingan di persidangan, maka petugas LKBH dan Pos Bantuan Hukum (Posbakum) akan memberikan informasi mengenai prosedur bantuan hukum di

\footnotetext{
${ }^{21}$ Wawancara, Tanggal 17 Juli 2017

${ }^{22}$ Edi Riyanto, MH (Bidang pendamping hukum di Litigasi/pengadilan) Wawancara 18 Juli 2017.
} 
pengadilan dan daftar organisasi bantuan hukum sebagaimana dimaksud dalam UU No. 16 Tahun 2011 Tentang Bantuan Hukum atau organisai bantuan hukum atau advokat lainnya yang dapat memberikan Bantuan Hukum Cumacuma.

Seperti yang disampaikan oleh Direktur LKBH IAIN Bengkulu (Dr. Imam Mahadi, SH., MH) setelah semuanya sudah masuk berkas ke Pos Bantuan Hukum yang ada di Pengadilan maka salah seorang petugas dari LKBH IAIN Bengkulu akan melakukan pendampingan yakni dengan cara memberikan pendampingan terkait masalah yang dihadapi sampai dengan proses persidangan ${ }^{23}$. Dan kemudian setelah semua berkas dari LKBH IAIN Bengkulu sudah lengkap, maka dilanjutkan ke Pos Bantuan Hukum yang ada, yakni dengan melengkapi beberapa berkas lagi sesuai ketentuan yang ada di Pos Bantuan Hukum yang tidak jauh berbeda dengan LKBH IAIN Bengkulu, yaitu antara lain:

1) Persyaratan Yang Harus Dipenuhi Untuk Mendapatkan Jasa Pos Bantuan Hukum (Posbakum) di Pengadilan Agama Kelas I A Bengkulu

Yang berhak menerima jasa dari Pos Bantuan Hukum (Posbakum) adalah pencari keadilan, terdiri dari perorangan atau sekelompok orang yang secara ekonomis tidak mampu atau memiliki kriteria miskin. Masyarakat yang secara obyektif membutuhkan bantuan hukum, maka Pos Bantuan Hukum di Pengadilan Agama menyediakan jasa secara cuma-cuma atau gratis, dengan biaya yang dibebankan kepada Mahkamah Agung Republik Indonesia. Maka mereka yang tidak mampu dari sisi ekonomi wajib melampirkan dokumen sebagai berikut:

- Harus melampirkan surat keterangan tidak mampu (SKTM) yang dikeluarkan oleh Kepala Desa/Lurah/Kepala Wilayah setingkat yang menyatakan bahwa benar yang bersangkutan tidak mampu membayar perkara, atau

- Surat Keterangan Tunjangan Sosial lainnya seperti Kartu Keluarga Miskin (KKM), Kartu Jaminan Kesehatan Masyarakat (Jamkesmas), Kartu Beras Miskin (Raskin), Kartu Program Keluarga Harapan (PKH), Kartu Bantuan Langsung Tunai (BLT), Kartu Perlindungan Sosial (KPS), atau dokumen lainnya yang berkaitan dengan penduduk daftar miskin dalam basis data terpadu pemerintah atau yang dikeluarkan oleh instansi lain yang berwenang untuk memberikan keterangan tidak mampu, atau

- Surat peryataan tidak mampu membayar jasa advokat yang dibuat dan ditandatangani oleh pemohon layanan Posbakum pengadilan dan disetujui oleh petugas posbakum pengadilan.

Dijelaskan juga oleh Betra Sarianti salah satu petugas yang ada di Pos Bantuan Hukum (Posbakum) di Pengadilan Agama Kelas I A Bengkulu ia mengatakan bahwa dengan adanya Posbakum diharapkan juga dapat

23 Dr. Imam Mahadi, SH., MH (Diirektur LKBH IAIN Bengkulu 2013-2016), Wawancara 18 Juli 2017. 
memberikan pencerahan dan penyuluhan hukum kepada masyarakat yang kurang dalam pemahaman terhadap hukum, hal ini bukan tanpa alasan kenapa Pos Bantuan Hukum (Posbakum) di peruntukan untuk masyarakat miskin, akan tetapi ini demi tercapainya proses peradilan yang efektif dan efisien baik dalam hal waktu dan biaya ${ }^{24}$. Pos Bantuan Hukum (Posbakum) tidak hanya membantu masalah perkara, namun dapat juga menjadi tempat masyarakat meminta konsultasi hukum terhadap permasalahan yang terjadi. masyarakat yang selama ini mengalami masalah komunikasi dalam hal menyelesaikan perkara di pengadilan agama akan mendapatkan kemudahan dengan datang ke Posbakum di Pengadilan Agama. Setelah para pihak pencari keadilan telah memenuhi persyaratan, adapun jenis layanan yang bisa diperoleh pada Posbakum yakni bantuan berupa pembuatan dokumen yang dibutuhkan untuk memperlancar jalannya persidangan, seperti pembuatan surat gugatan atau permohonan, dan bantuan berupa informasi, konsultasi serta advis hukum.

1. Pemberian Bantuan Hukum di Pos Bantuan Hukum (Posbakum) di Pengadilan Agama

Pemberian bantuan hukum Posbakum sama dengan yang ada di LKBH IAIN Bengkulu hal ini sesuai dengan 32 PERMA No. 1 Tahun 2014, yakni dimulai dari pengajuan bantuan hukum sampai dengan pendampingan hukum di Pengadilan. Selain itu ada beberapa jasa yang diberikan oleh Posbakum sperti yang dijelaskan oleh Ansori .F selaku petugas yang ada di Pos Bantuan Hukum Pengadilan Agama Kelas IA Bengkulu, Setidaknya ada empat jasa utama yang diberikan oleh pihak Pos Bantuan Hukum (Posbakum) yang berada di Pengadilan Agama Keslas I A bengkulu pada umumnya yaitu ${ }^{25}$ :

\section{a. Informasi}

Seperi telah disinggung di atas, salah satu jasa yang diberikan oleh Pos Bantuan Hukum (Posbakum) di Pengadilan Agama Kelas I A Bengkulu adalah memberikan informasi yang jelas pada setiap orang yang ingin mengajukan permohonan penyelesaian perkara di Pengadilan Agama Kelas I A Bengkulu melalui jalur Pos Bantuan Hukum (Posbakum) di Pengadilan Agama Kelas I A Bengkulu tersebut. Informasi ini seperti tentang prosedur dan persyaratan yang harus di penuhi oleh setiap yang ingin mengajukan permohonan bantuan hukum melalui Pos Bantuan Hukum (Posbakum) yang ada di Pengadilan Agama Kelas I A Bengkulu.

\section{b. Konsultasi}

\footnotetext{
${ }^{24}$ Betra Sarianti Sidik Aulia. Petugas di Pos Bantuan Hukum (Posbakum) Pengadilan Agama Kelas IA Bengkulu, Wawancara. Tanggal 17 Juli 2017

25 Ansori F. Petugas di Pos Bantuan Hukum (POSBAKUM) Pengadilan Agama Kelas IA Bengkulu, Wawancara. Tanggal 17 Juli 2017
} 
Menurut Ansori. F, konsultasi disini dalam artian bahwa setiap yang ingin mengajukan permohonan bantuan hukumnya kepada pihak Pos Bantuan Hukum (Posbakum) dapat menceritakan terlebih dahulu apa yang menjadi duduk perkara yang mereka hadapi ${ }^{26}$. Ini penting bagi mereka yang ingin menyelesaikan perkara atau permasalahannya di Pengadilan Agama baik berupa masalah cerai gugat, hak asuh anak, itsbat nikah ataupun permasalahan yang berhubungan dengan keluarga yang mereka sedang hadapi. Menurut Pujianti, mengetahui permasalahan yang sedang mereka hadapi adalah salah satu hal yang sangat penting untuk dilakukan karena ini akan menyangkut bagaimana cara penyelesaian perkara itu sendiri nantinya ${ }^{27}$.

\section{c. Advis}

Advis disini bisa diartikan sebagai saran, artinya adalah bantuan hukum yang disediakan oleh pihak Pos Bantuan Hukum (Posbakum) di Pengadilan Agama adalah memberikan masukan atau saran hukum kepada mereka yang mengajukan permohonan bantuan hukumnya kepada pihak Pos Bantuan Hukum (Posbakum) yang ada di Pengadilan Agama Kelas I A Bengkulu, hal ini diberikan dalam rangka tindak lajut dari konsultasi yang telah disebutkan di atas. Rudi, SH. menyebutkan dalam petikan wawancaranya bahwa setiap orang yang mengajukan perkara ke pihak Pos Bantuan Hukum (Posbakum) di Pengadilan Agama Kelas I A Bengkulu tidak serta merta langsung diarahkan untuk mempercepat proses penyelesaian perkara di pengadilan, namun mereka juga memberikan saran atau jalan keluar yang lebih baik ${ }^{28}$. Contoh dalam kasus perceraian, mereka tidak langsung merekomendasikan untuk langsung membuat surat gugatan, namun memberikan saran yang memungkinkan mereka untuk tidak terburu-buru dalam mengambil sikap, karena jika perceraian itu sudah dilakukan maka akan banyak berdampak pada hubungan kekeluargaan kedua belah pihak yang melangsungkan perceraian tersebut nantinya.

\section{d. Pembuatan Surat Gugatan}

Pembuatan surat gugatan adalah salah satu dari beberapa jasa yang disediakan oleh Pos Bantuan Hukum (Posbakum) di Pengadilan Agama Kelas I A Bengkulu. Hal ini diberikan untuk menghindari banyaknya kesalahan yang akan terjadi dalam pembuatan surat gugatan itu sendiri. Masyarakat yang kurang memahami hukum terkadang akan kesulitan untuk membuat surat gugatan yang menjadi salah satu dokumen penting jika seseorang tersebut ingin mengajukan

\footnotetext{
${ }^{26}$ Ansori F. Petugas di Pos Bantuan Hukum (POSBAKUM) Pengadilan Agama Kelas IA Bengkulu, Wawancara. Tanggal 17 Juli 2017

${ }_{27}$ Pujianti. Petugas di Pos Bantuan Hukum (POSBAKUM) Pengadilan Agama Kelas IA Bengkulu, Wawancara. Tanggal 17 Juli 2017

${ }_{28}$ Rusdi F, SH. Advokat di Pos Bantuan Hukum di Pengadilan Agama Kelas IA Bengkulu, Wawancara. Tanggal 17 Juli 2017.
} 
perceraian. Karena ini memerlukan pemahaman dan ketelitan sehingga dapat meminimalisir kesalahan yang akan terjadi dalam pembuatannya ${ }^{29}$.

Jasa bantuan hukum di Pengadilan Agama lebih kepada penyelesaian syarat administrasi saja sampai perkara yang akan diajukan ke Pengadilan Agama tersebut diterima dan dapat disidangkan dimuka pengadilan sebagai akhir dari setiap perkara yang akan diselesaikan nantinya. Hal ini bukan tanpa alasan mengapa dari pihak Pos Bantuan Hukum (Posbakum) di pengadilan Agama Kelas I A Bengkulu mempunyai banyak keterbatasan dalam memberikan bantuan hukumnya. Biaya yang terbatas yang disediakan oleh pemerintah, keterbatasan waktu untuk melayani setiap permasalahan yang diajukan dan banyaknya permintaan yang masuk ke Pos Bantuan Hukum (Posbakum) ke Pengadilan Agama Kelas I A itu sendiri.

Jadi pemberian bantuan hukum kepada masyarakat yang miskin atau kurang mampu, harus sesuai dengan PERMA No. 1 Tahun 2014 yakni, mengajukan permohonan bantuan, mengisi formulir dan mengikuti ketentuan yang berlaku, sesuai prosedur dan tata cara dalam menerima bantuan hukum.

Dari hasil wawancara dengan Direktur LKBH IAIN Bengkulu (Masril, SH., MH) pemberian bantuan hukum kepada masyarakat miskin atau kurang mampu tetap berjalan, akan tetapi semenjak menjadi bagian dari pengurus LKBH IAIN Bengkulu belum ada masyarakat yang memohon pengajuan untuk dilakukan pendampingan ${ }^{30}$.

a. Tanggapan/respon Masyarakat Penerima Bantuan Hukum oleh LKBH IAIN Bengkulu

Lembaga Konsultasi Bantuan Hukum (LKBH) IAIN Bengkulu sejak beridiri tahun 2013 sampai sekarang masih menerima dan memberikan bantuan hukum kepada masyarakat yang kurang miskin/mampu. Berikut tanggapan/respon dari masyarakat penerima bantuan hukum.

\section{Prosedur dan Tata cara Pengajuan Bantuan Hukum di LKBH IAIN Bengkulu.}

Dari hasil wawancara dengan salah seorang penerima bantuan hukum mengatakan bahwa, pelayanan bantuan hukum yang diberikan oleh LKBH IAIN Bengkulu sangat baik dan sesuai dengan prosedur yang ada. Seperti mulai dari penyampaian berkas petugas LKHB IAIN Bengkulu sangat respon dan tanggap sekali dengan situasi dan keadaan ketika kami sampai yang disambut dengan baik ${ }^{31}$.

29 Rudi F, SH. Advokat di Pos Bantuan Hukum di Pengadilan Agama Kelas IA Bengkulu, Wawancara. Tanggal 17 Juli 2017 2017.

${ }^{30}$ Masril, Direktur LKBH IAIN Bengkulu Periode 2016-2017, Wawancara, Agustus

${ }^{31}$ Wawancara dengan Ibuk Nurmala, 5 Agustus 2017 
Berbeda dengan Bapak Ujang, petugas LKBH IAIN Bengkulu sangat merespon sekali keluhan-keluhan yang saya sampaikan, dan mereka menyadari bahwa kami datang ke LKBH IAIN Bengkulu dikarena dalam segi ekonomi kurang mampu, sehingga kami dibantu sampai permasalahan kami tersebut tuntas, mulai dari pengumpulan berkas, pengisia formulir sampai dilimpahkan ke Pos Bantuan Hukum yang ada di Pengadilan Agama ${ }^{32}$.

Adapun saran dan masukan dari responden terkait sarana dan prasarana LKBH IAIN Bengkulu, ketika kami mau konsultasi terkait permasalahan yang kami hadapi, tempat untuk konsultasi kurang representatif/ tidak pas untuk mengadakan diskusi/dialog sebab dilakukan di tempat yang agak umum, hal ini sarana atau tempat konsultasi bantuan hukum pada saat itu dilakukan ditempat yang lain, bukan diruang khusus LKBH IAIN Bengkulu ${ }^{33}$.

Sekali lagi kami atas nama masyarakat sangat berterima kasih dengan adanya LKBH IAIN Bengkulu, selain memberikan bantuan layanan hukum, pihak $\mathrm{LKBH}$ memberikan masukan dan nasehat yang sangat baik terkait permasalahan yang sedang kami hadapi. Sehingga permasalahan kami tidak sampai ke jalur pengadilan ${ }^{34}$.

\section{Pemberian Bantuan Hukum di Pos Bantuan Hukum di Pengadilan Agama.}

Keberadaan pastinya sangat bermanfaat bagi mereka - mereka yang akan mencari keadilan namun mereka awam akan hukum. Disanalah peran atau kinerja Posbakum akan berjalan. Oleh karena itu ada setiap Pengadilan Agama dibentuk Pos Bantuan Hukum yang mana pembentukannya dilakukan secara bertahap. Dikarenakan Posbakum harus dimiliki oleh setiap Pengadilan Agama, maka pihak Pengadilan Agama juga harus menyediakan ruangan dan fasilitas bagi Posbakum itu sendiri. ${ }^{35}$

Jenis Jasa Hukum dalam Posbakum berupa:
a. Pemberian Informasi.
b. Konsultasi.
c. Advis.
d. Pembuatan surat gugatan.

Posbakum sendiri dalam melaksanakan tugas - tugas tersebut Posbakum Pengadilan Agama juga mempunyai berkewajiban untuk:

a. Melaporkan setiap penggunaan anggaran negara yang digunakan untuk pemberian Bantuan Hukum berdasarkan Undang-Undang.

32 Wawancara dengan Bapak Ujang, 12 Agustus 2017

33 Wawancara dengan Bapak Budianto, 13 Agustus 2017

34 Wawancara dengan Ibu Marjiana, 13 Agustus 2017

35 Pasal 16. Lampiran B, SEMA Republik Indonesia Nomor 10 Tahun 2010. Tentang Pedoman Pemberian Bantuan Hukum 
b. Menjaga kerahasiaan data, informasi, dan/atau keterangan yang diperoleh dari Penerima Bantuan Hukum berkaitan dengan perkara yang sedang ditangani, kecuali ditentukan lain oleh undang-undang.

c. Memberikan Bantuan Hukum kepada Penerima Bantuan Hukum berdasarkan syarat dan tata cara yang ditentukan dalam UndangUndang ini sampai perkaranya selesai, kecuali ada alasan yang sah secara hukum. ${ }^{36}$

Selain itu keberadaan Posbakum tidak dapat dituntut secara perdata maupun pidana dalam memberikan Bantuan Hukum yang menjadi tanggung jawabnya yang dilakukan dengan iktikad baik di dalam maupun di luar sidang pengadilan sesuai Standar Bantuan Hukum berdasarkan peraturan perundangundangan atau Kode Etik Advokat.

Ada beberapa syarat untuk menjadi pelaksana program Posbakum di Pengadilan Agama. Diantaranya adalah:

a. Berbentuk badan Hukum.

b. Berdomisili di wilayah hukum pengadilan

c. Memiliki pengalaman dalam menangani perkara.

d. Memiliki minimal satu orang advokat.

e. Memiliki staf atau anggota yang nantinya diperkerjakan di Posbakum, dimana staf atau anggota tersebut minimal lulusan sarjana hukum syariah.

f. Lulus tes kwalifikasi yang ditetapkan oleh pengadilan. ${ }^{37}$

Pengadilan agama juga diwajibkan menyediakn ruangan demi berjalannya kinerja dari Posbakum meski dengan sarana seadanya. Sehingga mereka para pencari keadilan lebih mudah jika ingin mendapatkan akses bantuan Posbakum. ${ }^{38}$

Pendanaan Bantuan Hukum yang diperlukan dan digunakan untuk penyelenggaraan Bantuan Hukum sesuai dengan Undang-Undang ini dibebankan kepada Anggaran Pendapatan dan Belanja Negara. Pemberi Bantuan Hukum dilarang menerima atau meminta pembayaran dari Penerima Bantuan Hukum dan/atau pihak lain yang terkait dengan perkara yang sedang ditangani Pemberi Bantuan Hukum. Karena biaya oprasional dari Posbakum ditanggung oleh negara, maka mekanisme pengawasan dan pertanggung jawaban Posbakum dilakukan oleh Ketua Pengadilan bersama-sama dengan organisasi penyedia jasa bantuan hukum. Selain itu Ketua Pengadilan Agama

\footnotetext{
${ }^{36}$ Pasal 10. Lembar Negara Undang-Undang Republik Indonesia No.16 Tahun 2011, Bantuan Hukum.

37 Pasal 27 Peraturan Mahkama Agung, No.01 Tahun 2014 Tentang Pedoman Pemberian Layanan Bantuan Hukum Bagi Masyarakat Tidak Mampu.

38 Pasal Pasal 23 ayat 4. Peraturan Mahkama Agung, No.01 Tahun 2014 Tentang Pedoman Pemberian Layanan Bantuan Hukum Bagi Masyarakat Tidak Mampu
} 
bertanggung jawab dalam pelaksanaan pemberian bantuan hukum, sedangkan Panitera Pengadilan Agama membuat buku registrasi khusus untuk mengontrol pelaksanaan pemberian bantuan hukum. Pemberi bantuan hukum wajib memberikan laporan tertulis kepada Ketua Pengadilan Agama. ${ }^{39}$

Pemberi Bantuan Hukum yang terbukti menerima atau meminta pembayaran dari Penerima Bantuan Hukum dan/atau pihak lain yang terkait dengan perkara yang sedang ditangani sebagaimana dimaksud dalam Pasal 20, dipidana dengan pidana penjara paling lama 1 (satu) tahun atau denda paling banyak Rp. 50.000.000,00 (lima puluh juta rupiah). ${ }^{40}$

\section{Tata Cara Beracara Melalui Posbakum}

Pemberian bantuan hukum bagi orang yang tidak mampu dimaksudkan sebagai suatu cara untuk memperbaiki ketidak seimbangan sosial. Seseorang yang mengajukan pemohonan untuk mendapat bantuan hukum harus menunjukkan bukti-bukti tentang kemiskinannya, misalkan dengan memperlihatkan suatu pernyataan dari Lurah yang disahkan Camat, mengenai penghasilannya yang rendah atau orang tersebut sama sekali tak berpenghasilan dan keterangan- keterangan lain yang berhubungan dengan kemiskinan.

Yang berhak mendapatkan jasa dari Pos Bantuan Hukum adalah orang yang tidak mampu membayar jasa advokat terutama perempuan dan anak-anak serta penyandang disabilitas, sesuai peraturan perundang-undangan yang berlaku, baik sebagai terdakwa maupun tersangka. ${ }^{41}$

Syarat untuk mengajukan permohonan pemberian jasa dari Pos Bantuan Hukum adalah dengan melampirkan:

a. Surat Keterangan Tidak Mampu (SKTM) yang dikeluarkan oleh Kepala Desa/Lurah/Banjar/Nagari/Gampong; atau

b. Surat Keterangan Tunjangan Sosial lainnya seperti Kartu Keluarga Miskin (KKM), Kartu Jaminan kesehatan Masyarakat (Jamkesmas), Kartu Program Keluarga Harapan (PKH), dan Kartu Bantuan Langsung Tunai (BLT); atau.

c. Surat Pernyataan tidak mampu membayar jasa advokat yang dibuat dan ditandatangani oleh Pemohon Bantuan Hukum dan diketahui oleh Ketua Pengadilan Agama.

Hal tersebut tidak jauh beda dengan yang tertulis pada undang-undang No.16 tahun 2011 yang menyatakan bahwa untuk memperoleh bantuan hukum, pemohon Bantuan Hukum harus memenuhi syarat-syarat:

\footnotetext{
39 Pasal 31. Lampiran B SEMA Republik Indonesia Nomor 10 Tahun 2010, Tentang Pedoman Pemberian Bantuan Hukum.

${ }^{40}$ Pasal 21. Lembar Negara Undang - Undang Republik Indonesia No.16 Tahun 2011, Bantuan Hukum.

${ }^{41}$ Pasal 16. Lampiran B, SEMA Republik Indonesia Nomor 10 Tahun 2010, Tentang Pedoman Pemberian Bantuan Hukum
} 
a. Mengajukan permohonan secara tertulis yang berisi sekurang kurangnya identitas pemohon dan uraian singkat mengenai pokok persoalan yang dimohonkan Bantuan Hukum.

b. Menyerahkan dokumen yang berkenaan dengan perkara

c. Melampirkan surat keterangan miskin dari lurah, kepala desa, atau

d. pejabat yang setingkat di tempat tinggal pemohon Bantuan Hukum.

e. Dalam hal pemohon Bantuan Hukum tidak mampu menyusun permohonan secara tertulis, permohonan dapat diajukan secara lisan.

Setelah membahas tentang persyaratan, selanjutnya mengenai mekanisme pendaftaran perkara melalui posbakum adalah dengan cara pemohon jasa bantuan hukum mengajukan permohonan kepada Pos Bantuan Hukum dengan mengisi formulir yang telah disediakan. Permohonan permohonan tersebut dilampiri fotocopy Surat Keterangan Tidak Mampu (SKTM) dengan memperlihatkan aslinya atau fotocopy Surat Keterangan Tunjangan Sosial lainnya dengan memperlihatkan ataupun surat pernyataan tidak mampu membayar jasa advokat.

Bagi para pemohon yang sudah mengisi formulir dan melampirkan SKTM dapat langsung diberikan jasa layanan bantuan hukum berupa pemberian informasi, advis, konsultasi dan pembuatan gugatan.

\section{Penutup}

Dari hasil pembahasan dan analisa peneliti, maka dapat disimpulkan:

1. Pemberian bantuan hukum kepada masyarakat miskin yang dilakukan oleh LKBH IAIN Bengkulu telah sesuai dengan PERMA No. 1 Tahun 2014, yaitu dengan cara; masyarakat/klien melakukan konsultasi; masyarakat melakukan pendaftaran dengan mengisi formulir; masyarakat mengajukan permohonan; Direktur melakukan penunjukan kosultan dan tim penanganan perkara baik litigasi maupun non litigasi, sampai dengan kasus/perkara selesai.

2. LKBH IAIN Bengkulu dalam melakukan pendampingan bantuan hukum bersifat terbuka dan kekeluargaannya tinggi yakni dimuali dari proses konsultasi, pendaftaran dan pengajuan permohonan, pendampingan klien dalam penanganan perkara, sampai dengan kasus/perkera selesai pihak LKBH IAIN Bengkulu menjalankan tugasnya dengan baik.

\section{Daftar Pustaka}

Pujiono, Bantuan Hukum dalam Perspektif Tanggungjawab Negara, Makalah disampaikan dalam Kegiatan Seminar "Bantuan Hukum dan Akses terhadap Keadilan Bagi Masyarakat Marginal’, Semarang, 09 Pebruari 2010

Justice for The Poor - The World Bank, Menciptakan Peluang Keadilan, Jakarta: The World Bank, 2005, hal 85 
Asfinawati, Prolog: Bantuan Hukum Cuma-Cuma dan Komersialisasi, dalam Lembaga Bantuan Hukum Jakarta, Bantuan Hukum Akses Masyarakat Miskin dan Marinal terhadap Keadilan, (akarta: LBH Jakarta, 2007, hal vi

Adnan Buyung Nasution, Pengantar Bantuan Hukum, dalam Lembaga Bantuan Hukum Jakarta, op.cit

Laporan Bank Dunia Tahun 2000/2001 dalam Povertry is Because Land' //www.grida.

H. Patrick Glenn dalam Justice for The Poor - The World Bank, Forging The Middle Ground- Engaging Non State Justice in Indonesia, Jakarta: The World Bank, 2008, hal 3

Cate Sumner, Memberi Keadilan Bagi Para Pencari Keadilan, Sebuah Laporan Tentang Pengadilan Agama Indonesia:Penelitian tabun 2007 tentang Akses dan Kesetaraan Jakarta: Mahkamah Agung dan Ausaid, 2008, hal 13-14

Ahmad F. Assegaf dkk, "Pandangan PBH PERADI terbadap RUU Bantuan Hukum Versi Badan Legislasi DPR - RI”, Jakarta: Juli 2010

Abdul djamal, Hukum Islam Berdasarkan Ketentuan Kurikulum Konsorsium Ilmu bukum. Cet 1, (Bandung: Maju Mundur, 2002), h. 98

Aldin Isri Mustofa, Terjemahan Shabih Muslim Jilid 1, ( Semarang :CV AsySyifa, 1998), h. 36

Jaenal Aripin, Himpunan Undang-Undang Kekuasaan Kebakiman. Cet ke 1, (Jakarta: Kencana Prenada Media grup, 2010), h. 637

Retno Wulan susanto, Iskandar Oeripkartawinata, Hukum Acara Perdata Dalam Teori dan Praktek. Cet ke 6, (Bandung :Penerbit Maju Mundur, 1979), h. 325

M. Yahya Harahap, Kedudukan kewenangan dan acara peradilan agama uи no. 7 tahun 1989. Cet ke 5, ( Jakarta:Sinar Grafika, 2009), h. $90-96$

Soerjono Soekanto dkk, Bantuan Hukum Suatu Tinjauan Sosial Yuridis, Cet. ke 1, (Jakarta: PT. Ghalia Indonesia, 1983), h. 14 